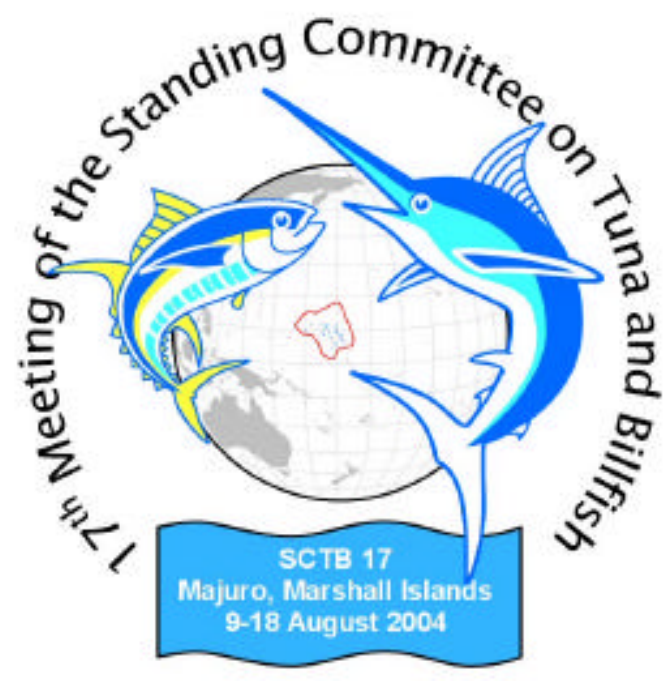

\title{
PERFORMANCE ASSESSMENT OF AN UNDERWATER SETTING CHUTE TO MITIGATE SEABIRD BYCATCH IN THE HAWAII PELAGIC LONGLINE TUNA FISHERY
}

Eric Gilman, Christofer Boggs, Nigel Brothers

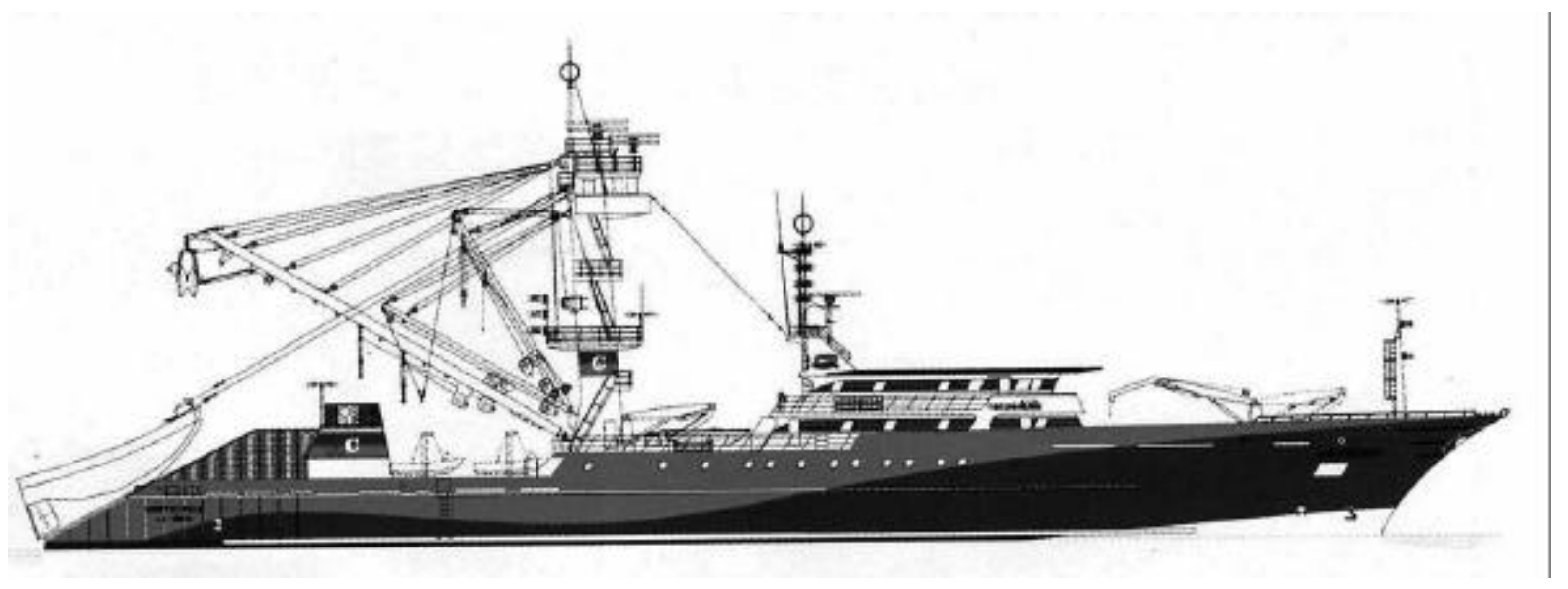

Blue Ocean Institute, 2718 Napuaa Place, Honolulu, Hawaii 96822 U.S.A.

U.S. NOAA Fisheries, Pacific Islands Fisheries Science Center, Honolulu, Hawaii, U.S.

Marine Ecology and Technology Consultant, Hobart, Tasmania, Australia 


\title{
Citation
}

Gilman, E., C. Boggs, and N. Brothers. 2003. Performance assessment of an underwater setting chute to mitigate seabird bycatch in the Hawaii pelagic longline tuna fishery. Ocean and Coastal Management 46(11-12): 985-1010.

\section{Title}

Performance Assessment of an Underwater Setting Chute to Mitigate Seabird Bycatch in the Hawaii Pelagic Longline Tuna Fishery

\section{Authors}

Eric Gilman ${ }^{\mathrm{a},{ }^{\star}}$, Christofer Boggs ${ }^{\mathrm{b}}$, Nigel Brothers ${ }^{\mathrm{c}}$

a Blue Ocean Institute, 2718 Napuaa Place, Honolulu, Hawaii 96822, USA

* Corresponding author. Tel.: +1-808-988-1976; fax: +1-808-988-1440. E-mail:

ericgilman@earthlink.net

${ }^{b}$ U.S. NOAA Fisheries Pacific Islands Fisheries Science Center, 2570 Dole Street, Honolulu, Hawaii 96822, USA

${ }^{\mathrm{C}}$ Marine Ecology and Technology Consultant, P.O. Box 81 Kettering, Tasmania 7155, Australia

\begin{abstract}
Mortality in longline fisheries is one of the most critical global threats to some seabird species. Underwater setting technology may offer an effective and commercially viable solution. The underwater setting chute for pelagic longline fisheries releases baited hooks underwater, out of sight and reach of diving seabirds. Results from a study in the Hawaii pelagic longline tuna fishery indicate that the underwater setting chute is the most effective technology tested to date to minimize seabird capture in this fishery. The chute eliminated seabird capture during this short-term trial. During control replicates, the capture rate was 4.24 captures per 1000 hooks and when normalized for albatross abundance, the rate was 0.114 captures per 1000 hooks per albatross. Expressed as contacts per 1000 hooks per albatross, the chute was 95\% effective at reducing albatross contacts with fishing gear compared to a control.

The chute was practical for use and design and installation improvements are likely possible to make the chute more palatable for uptake by industry. The chute has the added benefit of increasing fishing efficiency. The cost for purchasing and installing the chute would be recouped after only a maximum of two fishing trips. Based on an assessment of bait retention and hook setting interval when using the chute versus setting conventionally, vessels would experience a gain in efficiency of between $14.7 \%$ and $29.6 \%$ when albatrosses are abundant. Economic incentives are essential to abate global seabird mortality in longline fisheries.
\end{abstract}

